\title{
CHANGES OF THE LATIN LANGUAGE IN AQUITAINE AS REFLECTED BY THE INSCRIPTIONS*
}

\begin{abstract}
Summary: The aim of this study is to demonstrate what kind of changes took place in the Latin language in Aquitaine according to the inscriptions. All of the relevant inscriptions were examined up to this time, so we can form an opinion on the remarks made by József Herman, who was the first to deal with the development of the Latin of the Three Gauls in detail and who intended to write the history of this language. The categories of the computerized database are used for the analysis of the changes and some examples for the changes found are mentioned.
\end{abstract}

Key words: Vulgar Latin, linguistic changes, mistake, inscription, syllable, consonant, vowel, Gaul

Within the project Historical Linguistic Database of Latin Inscriptions of the Imperial Age I have examined the inscriptions of the Tres Galliae, which consist of three provinces: Aquitania, Belgica and Lugdunensis. First, I started to deal with the inscriptions of Aquitaine, and I have examined the latest edition containing these inscriptions in six volumes: Inscriptions Latines d'Aquitaine (henceforth ILA), Vuilleumier's collection, the Inscriptions Latines des Trois Gaules, the relevant inscriptions in the L'Année Épigraphique, the Corpus Inscriptionum Latinarum and the Recueil des inscriptions chrétiennes de la Gaule 8. (Aquitaine Première). However, there is a great problem with these collections: except for the ILA and the Recueil des inscriptions chrétiennes de la Gaule 8, they do not date the inscriptions (439 of the 950 data cannot be dated up to this time), although it would be necessary to establish when the linguistic changes took place in the Latin of Gaul. So far, 2834 inscriptions have been found, which are examined in the present study.

* I would like to express my gratitude to Dr. Béla Adamik for the opportunity to take part in the project OTKA (Hungarian Scientific Research Fund) No. K 62032 entitled "Computerized Historical Linguistic Database of Latin Inscriptions of the Imperial Age". It is a great honour to continue the research that aims at exploring and describing the Latin of Gaul and which was started by Professor József Herman. 
Before presenting what kind of Vulgar Latin features appear in these inscriptions, we have to establish some important factors. Firstly, the number of the inscriptions preserved in the territory of the Three Gauls is very small compared to other Roman provinces. While Italy shows a value of 13 inscriptions/100 ha, Africa 12, Gallia Narbonensis 6.1, Aquitania and Lugdunensis show values of only 1.1 inscriptions, and Belgica a value of 1.9. ${ }^{1}$ These low values are due to the extremely irregular distribution of the inscriptions. The density of the inscriptions, which is an index of Romanization, is influenced by various factors. Firstly, there are geographical factors, especially mountains and river valleys, which had an effect on the distribution. Concentrations of inscriptions tend to be larger in river valleys, as in the Rhône valley, but there are very few inscriptions in the mountains, which had been areas of low population in every period. ${ }^{2}$ The second major factor seems to have been the Roman communication system. Towns, which were situated at key points on the road network, and usually were administrative and cultural centres, produced much more inscriptions than other towns of similar size with fewer connecting roads and those of less importance. ${ }^{3}$ Thirdly, the Roman colonial and military establishment accounts for many of the details of the distributions. ${ }^{4}$ Along the line of the frontiers, the concentration of inscriptions is larger than in the demilitarized areas.

Furthermore, it is important to emphasize some general facts concerning the Latin language of Gaul. First and foremost, because of the paucity of the people represented in inscriptions we cannot draw conclusions from the grammatical mistakes regarding the everyday usage of Latin in the whole population of Gaul. We are only able to inspect what kind of changes took place in the spoken Latin in the background of the texts. In addition, Celtic dialects that were spoken by the inhabitants co-existed with Latin and as a result a different kind of bilingualism could develop here. It is possible that the use of Latin and Celtic was functionally separated in a community: Celtic was used at home and in private life, while Latin was the language of administration. ${ }^{5}$ In one of his articles, József Herman describes the characteristics of the Latin in Gaul: he states that consonants were relatively stable, while vowels were quite apt to change. ${ }^{6}$ He also claims that the changes of the vowels $e$ and $i$ are more frequent in this province than in the others, but the changes of the vowels $o$ and $u$ are rare and isolated compared to the changes of $e$ and $i$. Moreover, Gaul preceded the other regions since here not only the vowels in unstressed syllables were subject to change, but also those in stressed syllables. ${ }^{7}$ The omission of final consonants, especially $m, s, t$ is comparatively rare here, although it was general elsewhere. The inconsistent use of the consonants $b$ and $v$ is almost non-existent in

${ }^{1}$ Woolf, G.: Becoming Roman: The Origins of Provincial Civilization in Gaul. Cambridge 1998, 83.

${ }^{2}$ E.g. WOOLF (n. 1) 88.

${ }^{3}$ E.g. WoOLF (n. 1) $88-89$.

${ }^{4}$ E.g. Woolf (n. 1) 90 .

${ }^{5}$ Herman, J.: La langue latin dans le Gaule romaine. In ANRW II.29.2. Berlin-New York 1983, 1045-1060, here 1051

${ }_{7}^{6}$ E.g. HERMAN: La langue latin (n. 5) 1055.

${ }^{7}$ E.g. HERMAN: La langue latin (n. 5) 1055. 
this province. ${ }^{8}$ The declensions and conjugations were relatively well preserved apart from the elimination of the fourth declension. ${ }^{9}$ To sum up, he claimed that the changes penetrated into Gaul slowly, so that the classical norm could survive here for a long time.

In the present study I would like to present the linguistic phenomena found in the inscriptions and added to the computerized database that deviate from the socalled classical norm. ${ }^{10}$ Furthermore, I intend to examine whether we can confirm Professor Herman's statements on the grounds of these data. In what follows I will use the categories of the database for presenting the linguistic data and I will also add some examples for the changes found. Naturally, there are instances which have an alternative code, too, and there are some data that are to be evaluated rather as orthographic errors (like $k$ used for $c$ ) than as linguistic ones.

It is difficult to distinguish purely orthographic errors from mistakes showing real linguistic changes. However, the grammarians of the Imperial Age may help us with this problem. Although they rarely remark on pronunciation, it can be useful to mention their observations. A grammarian called Sacerdos (3rd century) presents the errors of the length of the vowels in final syllables ${ }^{11}$ and condemns it as "barbarismus nostri temporis". ${ }^{12}$ A century later another grammarian, Sergius extends the observation to the vowels that are long by nature: "Syllabas natura longas difficile est scire, sed hanc ambiguitatem sola probant auctoritatis exempla, cum versum poetae scandere coeperis". ${ }^{13}$ The grammarian Consentius ${ }^{14}$ in the fifth century adds an essential aspect to the description of this change: stressed vowels became long, while unstressed vowels were shortened even if they were long by nature. ${ }^{15}$ As Herman notes, ${ }^{16}$ the changes of short and long vowels were always considered errors and even barbarisms, while the fusion of timbre was described neutrally, without any condemning remarks added. ${ }^{17}$ These two kinds of changes had never been mentioned

${ }^{8}$ E.g. HERMAN: La langue latin (n. 5) 1056.

${ }^{9}$ E.g. HERMAN: La langue latin (n. 5) 1056-1057.

${ }^{10}$ Herman, J.: Late Latin Data Base: Guidelines for Data Collection. (Institute for Linguistics of the Hungarian Academy of Sciences; manuscript) Budapest 1990, 199.

${ }^{11}$ Herman, J.: Un aspect de la transition du Latin au Roman: les changements de la langue et leur reflet dans la conscience métalinguistique de la communauté. Aemilianense 1 (2004) 271-287, esp. 278.

${ }_{13}^{12}$ Grammatici Latini VI 493-494.

${ }^{13}$ Grammatici Latini IV 522.

${ }_{15}^{14}$ Grammatici Latini $\mathrm{V} 392,3$ and 12.

${ }^{15}$ HeRMAN: Un aspect (n. 11) 278.

${ }^{16}$ HERMAN: Un aspect (n. 11) 281.

${ }^{17}$ Servius: Vocales sunt quinque, a e i o $u$. Ex his, duae, e et o, aliter sonant productae, aliter correptae. Nam o productum quando est, ore sublato vox sonat, ut Roma, quando correptum, de labris vox exprimitur, ut rosa. Item e quando producitur, vicinum est ad sonum i litterae, ut meta, quando autem correptum, vicinum est ad sonum diphthongi, ut equus. Grammatici Latini IV 421, 16-21.

Pompeius: dicit ita Terentianus: quotienscumque e longam volumus proferri, vicina sit ad i litteram. Ipse sonus sic debet sonare, quomodo sonat i littera. Quando dicis evitat, vicina debet esse, sic pressa, sic angusta, ut vicina sit ad i litteram. Quando vis dicere brevem e, simpliciter sonat... Grammatici Latini $\mathrm{V} 102$. 
together by the grammarians; the differences of timbre were regarded as additional elements of the pronunciation in the normative description of the vowel system. ${ }^{18}$

In the 2834 inscriptions examined there were 115 non-linguistic mistakes. These are the following: litterae perperam incisae occurred 66 times, for instance $f t$ for et or eilia for filia; litterae omissae occurred 37 times, for example ceta for certa or pondum for ponendum; and there were only three examples for abbreviationes insolitae: hots for hostiis and meme for memoriae. Litterae superfluae appeared only seven times: dismisit for dimisit, votuum for votum, huiius for huius (according to Pirson ${ }^{19}$ it was a relatively frequent phenomenon to insert an $i$ (pronounced $j$ ) into the hiatus, but this is the only instance of this in Aquitaine), exanimen for exanime (it can be also regarded as masc. pro neutr. with $n$ for $m$ at the end of the word), uhic for hic (it can also be regarded as prosthesis, but surprisingly here a $u$ is inserted instead of the most frequently used $i$ ), siuis for suis. Finally, syllaba perperam adiuncta, that is, dittography occurred only twice: fifilia for filia and locucum for locum.

There were 835 linguistic errors, 754 of which were phonetic. In 473 cases vowels changed and in 281 cases consonants. Among the vowels errors 51 were made in the stressed syllable. We can provide only one example from the 2 nd century where short $e$ became $i$ in Siline pro Selenae, but there are 15 examples (most of them from the 6th century) where é: became $i$, for instance requiiscit for requiescit (4 times), rigno for regno (3 times), minsis and minses for menses, tris for tres and $t i$ for $t e$. This occured mostly in closed syllables. Short $i$ became $e$ only six times: $D u$ metio for Domitio, septuagenta for septuaginta, sene for sine, ponteficis for pontificis, megrans for migrans and prencepe for principe. There is only one example where $o$ : became $u$ in amature for amatore, while short $u$ became $o 20$ times (dated from the sixth century) in tomolo for tumulo, once in com for cum, once in iovenem for iuvenem and once in tolit for tulit. We have one example where $u$ : became $o$ in pedatora for pedatura. The diphthong ae became $e$ in five instances in a stressed syllable: quero for quaero, Cnei for Cnaei, prestitit for praestitit, que for quae, seclis for saeclis (they are from the 1st, 2nd and 3rd-6th centuries). In aeres for heres, which occurred twice and can be dated to the first century, the long $e$ became a diphthong $a e$.

422 mistakes were made in the unstressed syllable. There are only four examples of $a$ becoming $e$, in one instance it was a long a: Adnametos for Adnamatus, Lectore for Lactorae, tribunicie for tribunicia and Musice for Musica. (As Pirson notes, ${ }^{20} a$ weakened to $i$ and because of the merging of long $e$ and short $i$ it could be written with an $e$.) The changes of $e$ and $i$ are frequent, there is $i$ for $e$ in 22 cases, for example cintenario for centenario, tenit for tenet, divota for devota, filiciter for $f e$ liciter (in these two latter instances the $e$ is long, it occurred in the inscriptions 9 times altogether). There is $e$ instead of $i$ in 38 cases, for instance solvet for solvit, transiet for transiit, morebus for moribus, fragele for fragile etc. The merging of

\footnotetext{
${ }^{18}$ HERMAN: Un aspect (n. 11) 282.

${ }^{19}$ PIRSON, J.: La langue des inscriptions Latines de la Gaule. Bruxelles 1901, 74.

${ }^{20}$ PIRSON (n. 19) 28.
} 
long (and short) $o$ : and short $u$ leads to the changes of $o$ and $u$, which occur many times in the inscriptions. There are 9 examples where $u$ was written instead of short $o$, for example amatur for amator, doctur for doctor, senatur for senator, Theudoberti for Theodoberti, Dumetio for Dometio and there are 28 examples where long o: changed, but all of them occurred in the plural accusative form of annus (annus for annos). $O$ for $u$ was also frequent, it occurred 30 times, for instance eorom for eorum, famola for famula, tomolo for tumulo, abstolit for abstulit, etc. ${ }^{21}$

The most frequent change (occurring 111 times) was $e$ used instead of $a e$ for example in maxime for maximae, memorie for memoriae, bone for bonae, nature for naturae, etc. ${ }^{22}$ The reason for this phenomenon is that the diphthong ae became a monophthong that sounded similar to $e^{23}$ On the other hand, $e$ instead of $a e$ occurred only 5 times: pacae for pace (twice), diae for die, salutae for salute and daeo for $d e o$. There is only one example in Aquitaine where the diphthong au became $o$ : copo for caupo. There was some hesitation in the use of $a u$ as early as the archaic period and although Classical Latin restored this diphthong as a norm, words with a monophthong like copo lingered on in the vernacular. Greek $v$ was written with $u$ or $i$ in Latin as an orthographic tradition, the former was more frequent in the archaic age, and the latter in the classical period. Nevertheless, we can find both of them in the Gallic inscriptions. There are 7 instances of $i, 5$ times in nimphis for nymphis, and twice in Eutichi and Eutiches for Eutychi and Eutyches, and there are two examples of $u$ in numphis for nymphis and in presbuteria for presbyteria. As Pirson notes, ${ }^{24}$ the language of epigraphy is in close connection with archaic Latin because the unstressed $i$ often becomes $u$ next to a labial consonant, which occurred 17 times: 4 times in Legitumus for Legitimus, 8 times in Maxumus/Maxuma for Maximus/Maxima, twice in Maritumus/Maritumae for Maritimus/Maritimae, once in lubens for libens, Zmunthio for Zminthio, Optuma for Optima (they can be regarded as archaisms and indicated with this alternative code).

$I$ for $u$ occurred 10 times, but only in monimentum for monumentum and in its different forms. There were 31 examples of syncope, for instance humlis for humilis, domni for domini, Mascli for Masculi etc., and 27 examples of apocope, for example matr for matri, Roman, for Romani, fratr for fratri etc. The contraction of double $i$ for example in Antoni for Antonii, in fili for filii, Iuli for Iulii was also frequent according to the inscriptions, it occurs 59 times, whereas the contraction of double $u$ was quite rare, there are only four examples for this phenomenon: sum for suum, Ingenus

\footnotetext{
21 "En syllable atone et devant $l$, la langue archaïque et vulgaire prononçait $o$, alors qu'on écrivait $u$ dans le latin classique et littéraire. Cet $o$ a persisté pendant toute la période impériale et notamment dans les inscriptions; il a survécu en italien dans des conditions identiques. Dans certains mots, cette voyelle est pour ainsi dire devenue normale." PIRSON (n. 19) 44.

${ }^{22}$ The monophthongization of ae took place already at the beginning of the Imperial Age, but the diphthong was restored in writing (and in the pronunciation) by educated persons as a standard. Therefore it cannot be regarded as a real phonological change of the Imperial Age. Instead, it reflects tendencies in orthography.

${ }^{23}$ HeRmAN, J.: Vulgar Latin. University Park, PA. 2000, 31.

${ }^{24}$ PirSON (n. 19) 37.
} 
for Ingenuus, the latter three times. ${ }^{25}$ There are two examples for the omission of $i$ followed by $e$ in requescet for requiescet. The omission of $i$ followed by a vowel occurred 11 times in the inscriptions, for example Aurelus for Aurelius, memorae for memoriae, conugi for coniugi. For the elimination of $e$ and $u$ in the same position there is only one example each: Thodorici for Theodorici and Febrarias for Februarias. The elimination of another vowel followed by a vowel occurred twice: Mais for Maias and Ilias for Iulias.

Concerning the changes of vowels, we can point out that the proportion of errors made in stressed syllables are much lower than in unstressed syllables; of all the errors the most frequent one was $e$ used instead of the diphthong $a e ; i$ became $e$ almost as many times as $e$ became $i$. There were fewer examples for using $o$ for $u$ had than for using $u$ for $o$. Consequently, we may modify Professor Herman's statement, because the confusion of $o$ and $u$ was more frequent in the inscriptions than the confusion of $e$ and $i$ in unstressed syllables, and actually there were more instances altogether for the former than for the latter. Thus it seems that the confusion of $o$ and $u$ was not an isolated phenomenon in this region, even if some of these errors can be considered as archaisms, too. Most of the confusion of $i \sim e$ can be dated to the sixth century (the earliest instance to the first), but as for the confusion of $o \sim u$ there were as many examples from the first and second centuries as from the sixth. There were

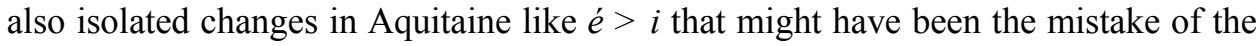
engraver or they might show the language use of a member of the deceased person's family rather than a real linguistic change in this area of Gaul.

As for the consonants, there was only one example for $d$ for $t$ between two vowels: condeda for condita. Intervocalic $c$ became $g$ once in Segundinus for Secundinus. There is only one instance for the elimination of intervocalic $g$ in Cintuenae for Cintugenae. Sonorisatio ante consonantem occurred three times in the inscriptions: Lezbiae for Lesbiae, Abrili for Aprili and Ghlotharii for Clotharii. We have only one example for the desonorisatio consonantis finalis in set for sed. The desonorisatio consonantis intervocalis occurred 23 times in the inscriptions: of these tauropolium for taurobolium occurred 20 times (it could have been affected by the Greek word Tаvролó $\lambda(\alpha)$; two examples concern g: Recinus for Reginus, Toci for Togi, and one example concerns $d$ : cupeta for cupida. The confusion of $b$ and $v$ occurred 7 times altogether: Vivio for Vibio, oviit for obiit twice, devetum for debitum, plevique for plebique, boto for voto and bixit for vixit (the dated examples are from the third and the next three centuries). The omission of intervocalic $v$ occurred 18 times: vius for vivus (14 times), Flainus for Flavinus, Lascius for Lascivus aunclus for avunculus. The elimination of $v$ between a consonant and a vowel occurred twice: conserus for conservus and serus for servus. ${ }^{26}$

\footnotetext{
${ }^{25}$ Like the monophthongization of $a e$, the contraction of $i$ and $u$ can also be regarded as an orthographic change because it took place earlier than the Imperial Age. Double vowels were restored in writing as a norm.

26 “'Et ce qui prouve clairement que l'emploi du signe $V$ pour $V V$ pouvait n'être qu'un procédé graphique. ... Cependant il parait bien établi que la généralité de ces graphies sans $v$ représentait la prononciation réelle." PIRSON (n. 19) 63.
} 
The labial element of $q u$ disappeared and gave way to the following form: reqescet for requiescet ( $q$ without $u$ ). In Vulgar Latin, $t$ before $i$, which sounded $j$ in the spoken language, became an affricate [ts], which is attested by the changes of $t$ and $c$ in the following examples: distancia for distantia, tercio for tertio, nacione for natione innocencius for innocentius (from the sixth century) and deposicio for depositio. $D$ before the same $i$ was eliminated as we can see in aiutit for adiutet. $Q$ for $c$ shows that after the elimination of the labial element of $q u$ these two graphs marked the same sound. There are three examples for this: quius for cuius, Pequliaris for Peculiaris (twice). There are three examples for $q / c / k$ for $q u$, too: reqescet for requiescit (twice) and qinta for quinta. As for the instances where word-initial $h$ is eliminated, we regarded them as data irrespective of whether they are only orthographic phenomena or not. It occurred 18 times like in eredes for heredes, umanis for humanis, $o c$ for hoc and it can also be seen in Greek words without the aspirate like Eutici for Eutychi, nimpis for nymphis, Zmintio for Zminthio, etc. Greek ph became a voiceless labiodental fricative during the fourth century ${ }^{27}$ and was preserved as $f$ in the inscriptions: neofiti for neophyti (from the fifth century). $K$ for $c$ is an orthographic change going back to the archaic period. There are 17 instances for it: karissimae for carissimae (14 times), vikanis for vicanis, Karinae for Carinae, Volkno for Vulcano. $N$ instead of $m$ occurred twice at the end of the word: annorun for annorum (it could be also the mistake of the engraver), exanimen for exanimem.

As for word-final consonants, there are 12 examples where $m$ was eliminated, for instance arce for arcem, arula for arulam, septe for septem etc. The omission of $s$ occurred 16 times, for example Sabinu for Sabinus, regi for regis, civi for civis, etc (the last two examples can be dat. pro gen.). $T$ disappeared at the end of the words 7 times: posui for posuit, feci for fecit, sin for sint, etc. There are other examples for the elimination of consonants in the following instances: $n c t$ became $n t$ twice in defunta for defuncta (this was frequent in Vulgar Latin), but we can find words where $c t$ was written instead of $n c t$, for instance defuctus for defunctus; $c t$ became $t$ once in strutores pro structores. $S$ disappeared from the sequence $n s$ five times, see traspecti for transpecti, trasiit for transiit, Masueta for Mansueta, Masueti for Mansueti and Masueto for Mansueto. There is one example where a simple $s$ became $n s$ in nepotins for nepotes. The most frequent change concerns the graph $x$; in 57 examples $x$ was written with two letters: mostly with an $x$ and an $s$ (sometimes with double $x$ ) as in Maxsimus for Maximus (7 times), uxsor for uxor (19 times), vixsit for vixit, Divixxti for Divixti; once $x$ was written with a simple $s$ in escepit for excepit (the former instances show rather orthographic changes while the latter one can also represent a phonological change). $N$ followed by a consonant (mostly by a dental) disappeared in 9 instances: ponedum for ponendum, Fracorum for Francorum, Advetinis for Adventinis.

There are five examples for dissimilation: inlustria for illustria, adfectione for affectione, conmilitiones for commilitiones, Ponponiae for Pomponiae, conlet for complet. We can find some examples in the inscriptions where simple consonants

${ }^{27}$ PIRSON (n. 19) 80. 
were geminated or, on the contrary, double consonants became simplified. Sometimes the engraver could make this kind of error but we can assume with good reason that this orthography reflects a feature of the spoken language, because it can be found in some inscriptions of other provinces. It mostly affects the following consonants in Aquitaine: $l, r, n, s$. Firstly, double consonants became simple ones in colegis for collegis, Apolini for Apollini, Eriapo for Erriapo (for $r$ this is the only example occurring 5 times), anorum for annorum (9 times), Succesa for Successa, nobillisimo for nobilissim, and there are two examples where double $t$ was simplified: quatuor for quattuor, Ulatios for Ulattios, and there is one instance where it happened to the graph $c$ : ecl for eccl(esiae). Secondly, simple consonants were geminated in the following words: Gallerius for Galerius, fillie for filie, nobillisimo for nobilissimo, Tautinni for Tautini, Anicianni for Aniciani, incisso for inciso, possuit for posuit, vissu for visu, transsiit for transit. And there are some examples where other consonants were geminated: Germaniccus for Germanicus, Erriappo for Erriapo, obblata for oblata.

It is clear from what has been said above that Professor Herman's statement that vowels were more affected by the changes than consonants proves to be right: there are 473 examples for the former and 281 for the latter. The changes of the graph $x$ were the most frequent, followed by devoicing in intervocalic position, the elimination of intervocalic $v$, and the disappearance of $h$. (The changes concerning $x$ and $h$ are orthographic rather than phonological.) The diagram shows that some of the changes, like desonorisatio consonantis finalis, were sporadic. The omission of final consonants was not frequent but it obviously existed in Aquitaine already in the first century. To sum up, it can be stated that the changes of consonants were not so considerable, because apart from some cases the examples are sporadic and isolated.

We have 81 examples for changes classified as morphosyntactica etc., but for most of these there are only a few instances. There are 17 examples for changes of cases altogether: accusative for nominative in Iulia Titiolam for Titiola; nominative for accusative in the Greek diathesis for diathesin; nominative for genitive in the name Onesicrate for Onesicratis; nominative for dative in the name Romulus for Romulo, uxor for uxore, Iuno for Iunoni (the examples of the last three categories can also be regarded as vocabula indeclinata); dative for genitive in nato for nati; genitive for dative in defuncti for defuncto and in the name of a Gallic god Leherenni for Leherenno; accusative for ablative in nepotins (nepotes) for nepotibus, pro salutem suam for pro salute sua, in pacem for in pace; ablative for dative in matre for matri (but it may also have been caused by the confusion of $e$ and $i$ ); genitive or dative for ablative in pecuniae suae for pecunia sua; dative or ablative for accusative in monimento for monumentum (it may also have been caused by the elimination of final $\mathrm{m}$ and the confusion of $o$ and $u$ ); accusative for genitive in memoriam for memoriae.

As for the changes of the genders there are three examples where masculine was used instead of feminine: deo for deae, sui for suae, qui for quae, and masculine is used for neuter in one instance: exanimen (= exanimem) for exanime. There were two inscriptions in which the suffix -is was replaced by -abus and -ibus: libertabus for libertis and dibus for diis. We can find one example for the confusion of the sec- 
ond and the fourth declensions, where the second was used instead of the fourth: ex viso for ex visu. There are three examples in the category of vocabula indeclinata: Veria for Veriae (it can also be a nominative for genitive), deae Diana for deae Dianae, gremium for gremio. Although we have 23 examples for the change in the form of the superlative, in most of the cases this concerns one word, namely the adjective pius: piissimae/piissimo and pientissimae/pientissimo for maxime piae/pio (22 times), and umilissimus for humillimus. There is only one example for the change of the numerals: ter was written with a Roman number instead of the right Roman numeral adverb. The preposition cum became con only in one inscription. The form coiugi/ coiux for coniugi/coniux, which occurred 7 times, can altogether be regarded as variatio praefixorum.

There were three examples for recompositio: consacravit for consecravit occurring three times. There are 4 words in the category of lexica: the adjective bone memorius (twice), which was formed from the well-known formula Dis Manibus et bonae memoriae as a Christian adjective in the fourth century; coniuga which is a feminine form to coniux, and Viennis for Viennensis. There was one example for a Graecismus in a metrical inscription: dabount for dabunt. According to the ILA $A^{28}$ ou instead of simple $o$ can emphasize that this syllable is long. As for archaisms, they occurred 8 times: faciundum for faciendum, conservos for conservus, vivos for vivus (four times), adoptivos for adoptivus, servos for servus, but we can also regard forms like Maxumus, tomolo, etc. as archaisms. And finally, there were some errors which could be regarded as hypercorrectio: thomolo for tumulo, hara for ara, hex for ex all of them with an $h$ added (so they can also be litterae superfluae), sribtis for scriptis, collabsa pro collapsa, and one of the forms of the irregular verb fero was once formed as regular: ferit for fert.

As can be seen from what has been said above, the proportions of morphological and syntactic errors are very low compared to the errors made altogether, and for most of them we have only one or a few examples, so it seems that they are isolated, and sometimes they reflect the incompetence of the engraver or the ordinator rather than changes of the spoken language. Only the change of the superlative occurs more than 10 times, but this is not representative because in most of the cases it concerns only one word, namely pius. ${ }^{29}$ To sum up, we can state that although there were signs of changes in morphology and syntax, they were sporadic at this time, the classical norm was relatively well preserved in the inscriptions.

Krisztina Fodor PhD Student

Eötvös Loránd University (ELTE) Budapest

Ancient Studies Doctoral Program

\footnotetext{
${ }^{28}$ Bost, J-P. - FABRE, G.: Inscriptions Latines d'Aquitaine - Pétrucores. Bordeaux 2001, 269.

${ }_{29}$ Mostly we find piissimo/piissima or pientissimo/pientissima in the inscriptions, so they can be regarded as changes of lexica.
} 

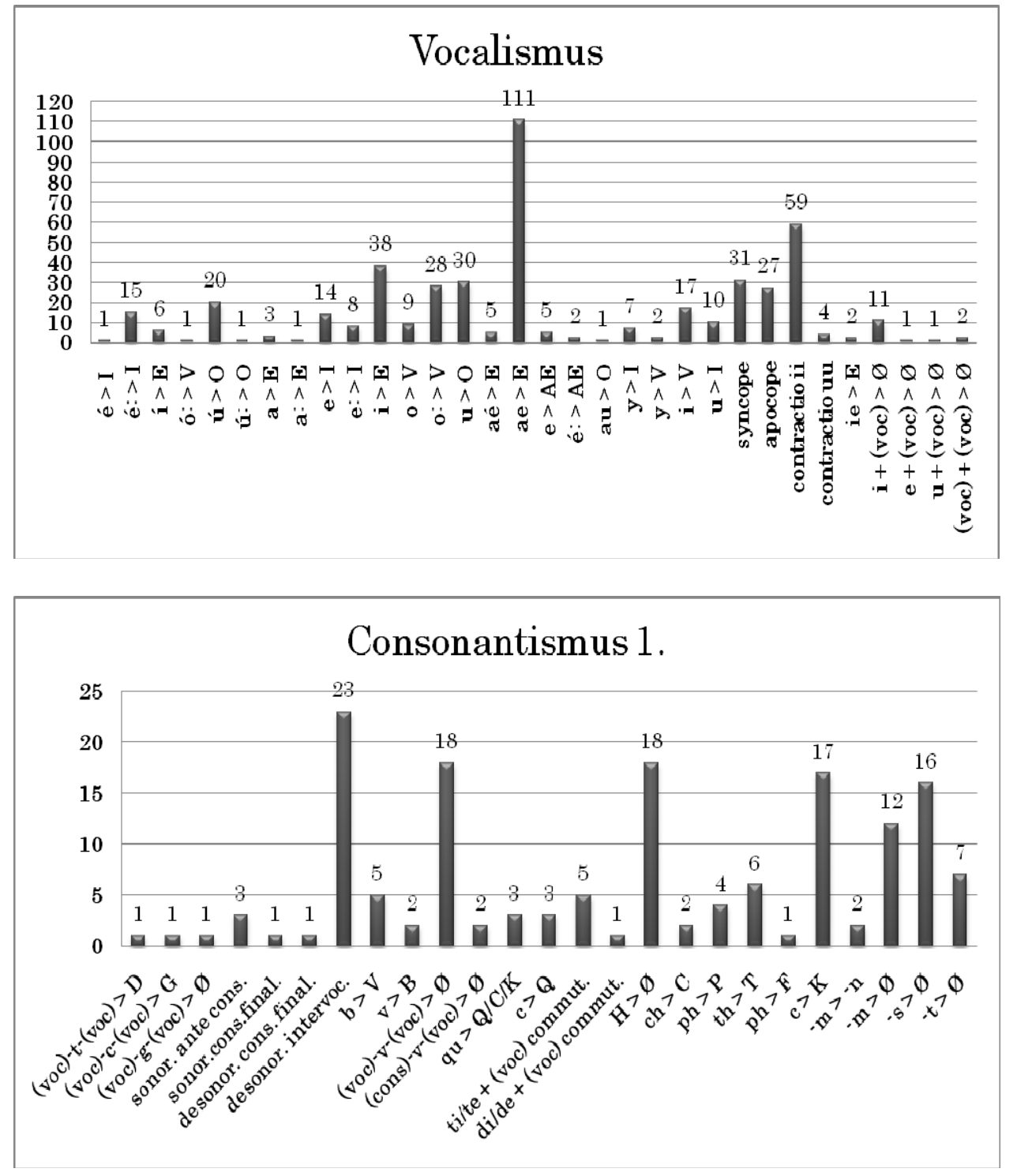

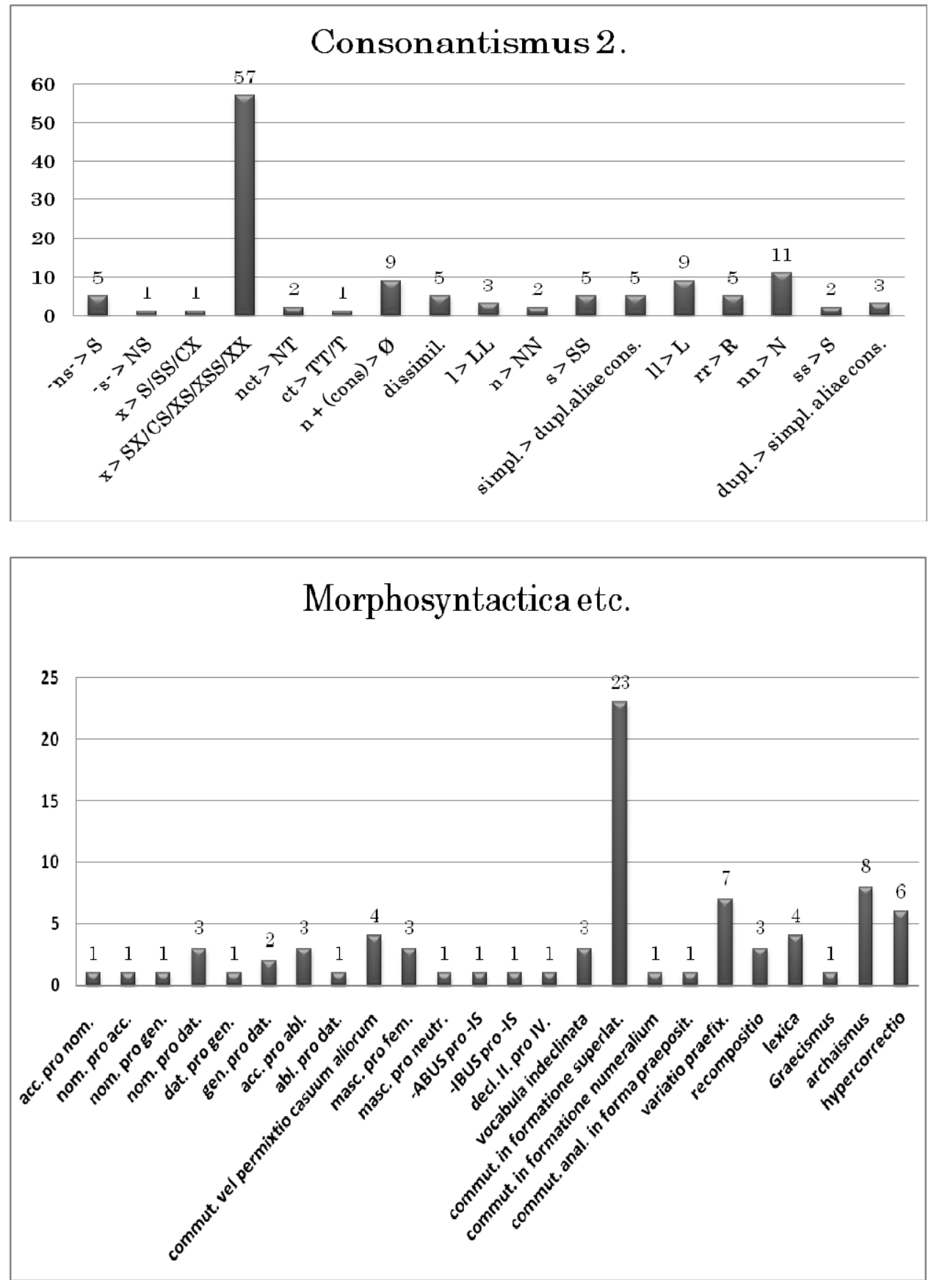


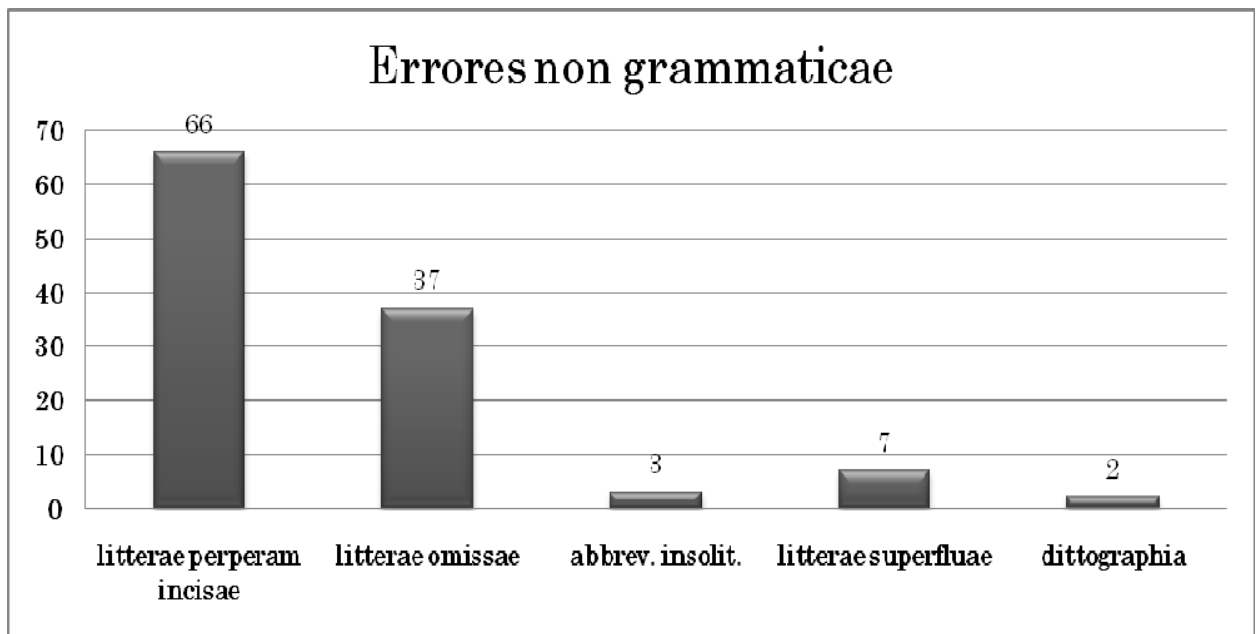

